\title{
Revised Accounting For Business Combinations
}

Arlette C. Wilson, Auburn University, USA

Kimberly Key, Auburn University, USA

\begin{abstract}
The Financial Accounting Standards Board (FASB) has recently issued Statement of Financial Accounting Standards No. 141 (Revised 2007) Business Combinations. The object of this Statement is to improve the relevance, representational faithfulness, and comparability of reported information about a business combination and its effects. This Statement replaces FASB Statement No. 141, but retains the fundamental requirements that the acquisition method of accounting (previously called the purchase method) be used for all business combinations. Some of the changes related to the accounting for business combinations as a result of the new requirements are discussed and illustrated below.
\end{abstract}

Keywords: Business combinations, purchase method, acquisition method, bargain purchase, goodwill, step acquisition

\section{CONTINGENT CONSIDERATION}

Dontingent consideration usually is an obligation of the acquirer of the business combination to transfer

6 additional assets or equity interests to the former owners of the acquiree as part of the exchange for control of the acquiree if specified future events occur or conditions are met. Previous accounting generally did not recognize an acquirer's obligation to make payments conditioned on the outcome of future events at the acquisition date. Acquirers generally recognized those obligations when the contingency was resolved and consideration was issued or became issuable. Although the amount of future payments the acquirer will make is conditional on future events, the obligation to make them if the specified future events occur is unconditional. Failure to recognize that obligation at the acquisition date would not faithfully represent the economic consideration exchanged at that date.

A contingent consideration arrangement is inherently part of the economic considerations in the negotiations between the buyer and the seller. Therefore Statement 141 (revised) requires that the acquirer recognize the acquisition-date fair value of contingent consideration as part of the consideration transferred in exchange for the acquiree. The corresponding obligation should be classified as a liability or as equity in accordance with FASB Statement No. 150 Accounting for Certain Financial Instruments with Characteristics of both Liabilities and Equity.

Subsequent changes in fair value of the contingent consideration depends on whether that contingent consideration is classified as equity or as a liability. Subsequent accounting for changes in fair value is as follows:

- $\quad$ Contingent consideration classified as equity will not be remeasured for changes in fair value and its subsequent settlement is to be accounted for within equity.

- Contingent consideration classified as a liability is remeasured to fair value at each reporting date until the contingency is resolved. The changes in fair value are recognized in earnings. (except if a cash flow hedging instrument). 
Example. On November 1, 2009 (date of acquisition), Company X agreed to an arrangement to pay additional consideration for the combination if the acquiree's 2010 earnings exceeds $\$ 300,000$. Company X will pay $10 \%$ of the reported earnings. At November 1, 2009, the acquiree's estimated earnings for 2010 is $\$ 400,000$.

Exhibit 1 includes both the accounting for this contingent consideration based on the delayed recognition of an additional element of cost and the new requirements of recognizing the acquisition date fair value of the contingent consideration as part of the cost of the acquisition. Previous accounting would not make an entry until the contingency is resolved. Therefore, at December 31, 2010 when the earnings for the year are known, the amount which is payable is recorded as an added cost of the acquisition. Assumption 3 would have no entries at all since the target earnings of $\$ 300,000$ was not achieved.

The revised accounting requires the fair value of the contingent consideration to be estimated and recorded as an added cost of the acquisition. Since earnings for 2010 is estimated to be $\$ 400,000$, the ten percent payable amount is recorded as an added cost of the acquisition. When the contingency is resolved, the liability is adjusted with the corresponding gain or loss included in earnings. Although not illustrated in this example, any change in fair value of the contingent consideration at December 31, 2007 as the result of a change in estimated future earnings would also be reported as a gain or loss in current earnings.

Note that the estimated fair value of the contingent consideration at acquisition date is the amount included in the acquisition cost. Any subsequent changes in the fair value are reported as gains or losses in current earnings. If earnings are higher than expected the increase in the liability and related loss are offset with higher than expected earnings. If earnings are lower than expected than the resulting decrease in the liability and corresponding gain partially offsets the lower earnings.

Example. On November 1, 2009 (date of acquisition), Company X issued 1,000,000 shares of its own $\$ 10$ par common stock with a fair value of $\$ 33.60$ per share. Company $X$ agreed to an arrangement that if the fair value of its stock was not at least $\$ 33.60$ per share on December 31, 2010, additional shares would be issued so that total fair value of issued shares would be $\$ 33,600,000$. At November 1, 2009, Company X estimates that its stock may drop in value to $\$ 32$.

Exhibit 2 includes both the current accounting and the revised accounting for this contingent consideration based on future security prices. Previous accounting would not make any entry until the contingency is resolved at December 31, 2010. Assumption 1 would result in Company X issuing an additional 120,000 shares so that total value of shares issued is $\$ 33,600,000(1,120,000$ shares @ $\$ 30)$. The per value of these additional shares is moved from paid in capital to common stock. Assumption 2 requires no additional shares and therefore no entry.

Revised accounting requires Company $\mathrm{X}$ to estimate the fair value of any additional shares that might be issued. Since Company X estimates the security price to decrease to $\$ 32$, they estimate that 50,000 additional shares may be issued December 31, 2010. The fair value of those shares are estimated at $\$ 1,600,000$ (50,000 sh. @ \$32). That estimated fair value is included as part of the acquisition cost on November 1,2009. If additional shares are issued as in Assumption 1, the settlement is accounted for in equity. If no additional shares are issued as in Assumption 2, no entry is needed.

\section{STEP ACQUISITION}

A corporation may acquire a target company in more than one transaction. For example, assume Company X holds a 30 percent equity interest in Company Y at December 31, 2008. By June 2009, Company X has purchased an additional 40 percent equity interest in Company $\mathrm{Y}$ which now gives Company $\mathrm{X}$ control.

Current accounting identifies the cost of investment, the fair value of the identifiable net assets, and the goodwill on each step. This method resulted in a blend of historical costs and fair values for the business combination. 
In order to provide better information, this Statement focuses on reporting all identifiable net assets at fair value at acquisition date. In a business combination achieved in stages, the acquisition date is when the acquirer achieves control. Therefore this Statement requires the acquirer in a business combination achieved in stages to recognize the identifiable assets and liabilities, as well as the noncontrolling interest in the acquiree, at the full amounts of their fair value. The acquirer should remeasure its previously held equity interest at its acquisition date fair value and recognize any resulting gain or loss in current earnings. Any amounts recognized in other comprehensive income because the investment was classified as available for sale should be reclassified and included in the calculation of gain or loss at the acquisition date.

Example. The following acquisition of Company S stock were made by Company P:

\begin{tabular}{|c|c|c|c|c|}
\hline Date & $\underline{\%}$ & $\underline{B o o k}$ Value & $\underline{\text { Fair Value }}$ & $\underline{\text { Cost }}$ \\
\hline Jan. 1, 2007 & $10 \%$ & $\$ 1,000,000$ & $\$ 1,200,000$ & $\$ 130,000$ \\
\hline Jan. 1, 2008 & $20 \%$ & $1,080,000$ & $1,300,000$ & 280,000 \\
\hline Jan. 1, 2009 & $40 \%$ & $1,170,000$ & $1,400,000$ & 600,000 \\
\hline
\end{tabular}

Company S reported net income and dividends as follows:

$\begin{array}{ccc}2007 & \frac{\text { Net Income }}{\$ 100,000} & \underline{\text { Dividends }} \\ 2008 & 110,000 & \$ 20,000 \\ & 10,000\end{array}$

The journal entries to account for the Investment for 2007 and 2008 are included in Exhibit 3. Since the investment was only 10 percent in 2007 , the cost method is used to record the dividend received. In 2008, significant influence is assumed with the 30 percent ownership interest. The Investment is converted to the Equity Method resulting in a credit to Retained Earnings of $\$ 8,000$. In 2007, Investment Revenue would have been $\$ 10,000(10 \% * \$ 100,000)$, but dividend revenue was only $\$ 2,000$. Therefore, there would have been $\$ 8,000$ more in revenue and the corresponding Investment account. The Equity method is subsequently applied for 2008.

On January 1, 2009, Company P acquires control when the 40 percent equity interest is acquired. Current accounting would only record the acquisition at cost. The revised accounting requires the previously held investment to be remeasured at acquisition-date fair value. Since $\$ 600,000$ was the fair value of a 40 percent interest, then a 70 percent interest would have a fair value of $\$ 1,050,000$ [\$600,000* $(70 \% / 40 \%)]$. The balance in the Investment account before adjusting to fair value is $\$ 1,045,000$. Therefore the Investment needs to be increased by $\$ 5,000$.

This gain is composed of the differences between change in book value and change in fair value for the respective percentage ownerships. Change in book value is included in the Investment account because the Equity method was used to account for the Investment. Book value changed from January 2007 to January 2009 by $\$ 170,000$, while change in fair value was $\$ 200,000$. Change in book value from January 2008 to January 2009 was $\$ 90,000$, while change in fair value was $\$ 100,000$. The gain is calculated as follows:

$10 \% * \$ 30,000=\$ 3,000$

$20 \% * 10,000=\underline{2,000}$

Total Gain $\quad \overline{\$ 5,000}$

The investment account will not reflect change in fair value after the acquisition date.

Example. The following acquisitions of Company S stock were made by Company P:

\begin{tabular}{lccrr} 
Date & $\%$ & Book Value & Fair Value & \multicolumn{1}{c}{ Cost } \\
January 1,2007 & $10 \%$ & $\$ 1,000,000$ & $\$ 1,200,000$ & $\$ 130,000$ \\
January 1,2009 & $50 \%$ & $1,200,000$ & $1,520,000$ & 800,000
\end{tabular}


The Investment had a market value of $\$ 138,000$ at December 31, 2007 and $\$ 150,000$ at December 31, 2008. At January 1, 2009 when control was obtained, the following adjusting entries were made:

$\begin{array}{lr}\text { Dr. Investment } & 30,000 \\ \text { Cr. Gain } & 30,000 \\ & \\ \begin{array}{l}\text { Dr. Unrealized Gain from } \\ \text { Available for Sale }\end{array} & \\ \text { Cr. Allowance } & 20,000 \\ & 20,000\end{array}$

The first entry adjusts the previous Investment of $\$ 130,000$ to reflect the acquisition date fair value of the equity interest $(\$ 800,000 / 50 \%=\$ 1,600,000 * 10 \%=\$ 160,000)$. The second entry removes the unrealized gain from accumulated other comprehensive income and the corresponding Allowance account that was used to adjust the Investment to its December 31, 2008 fair value of \$150,000. In the Comprehensive Income Statement, this $\$ 20,000$ would be reported as a reclassification in other comprehensive income.

\section{CALCULATION OF GOODWILL}

There currently exists alternative methods for the reporting of goodwill:

- $\quad$ Full goodwill method which reports both the parent's share and the noncontrolling interest's share of goodwill.

- $\quad$ Partial goodwill method which reports only the parent's share of goodwill.

To improve the completeness of the resulting information and make it more comparable across entities, only the full goodwill method is now acceptable. The Statement requires noncontrolling interest to be measured at fair value which will result in recognizing goodwill attributable to the noncontrolling interest as well as the goodwill attributable to the acquirer. The acquirer's goodwill is measured as the excess of (a) over (b) below:

(a) The aggregate of:

- $\quad$ Acquisition-date fair value of consideration transferred

- $\quad$ Fair value of noncontrolling interest

- In a business combination achieved in stages, the acquisition-date fair value of the acquirer's previously held equity interest in the acquiree

(b) The net of the acquisition-date fair values of the identifiable assets acquired and liabilities assumed.

Measuring the fair value of the noncontrolling interest can be based on the market price for the shares not held by the acquirer. The fair values of the acquirer's interest in the acquiree and the noncontrolling interest on a per-share bases might differ because of an inclusion of a control premium in the per-share fair value of the acquirer. In situations when an active market price for equity shares is not available, the acquirer should measure the fair value of the noncontrolling interest using other valuation techniques.

Example. Company P acquires $80 \%$ of Company S's 400,000 outstanding shares for $\$ 8,000,000$. Fair value of identifiable assets and assumed liabilities are measure as $\$ 25,000,000$ and $\$ 16,000,000$, respectively.

Assuming no control premium and that per-share fair value is the same for both the acquirer and the noncontrolling interest, then the fair value of the noncontrolling interest is measured as follows:

80,000 shares @ $\$ 25=\$ 2,000,000$ 
The noncontrolling interest is holding $20 \%$ of the 400,000 shares. The per-share fair value is $\$ 25$ since Company P paid $\$ 8,000,000$ for 320,000 shares. Goodwill is calculated as follows:

Fair value of consideration transferred.

Fair value of noncontrolling interest.

Fair value identifiable net assets.

Goodwill...

$$
\begin{array}{r}
\$ 8,000,000 \\
2,000,000 \\
\hline \$ 10,000,000 \\
9,000,000 \\
\hline \$ 1,000,000 \\
\hline \hline
\end{array}
$$

Of the $\$ 1,000,000$ of goodwill, $\$ 800,000$ is attributable to Company $\mathrm{P}$ and the other $\$ 200,000$ is attributable to the noncontrolling interest.

Example. Company P acquires $80 \%$ of Company S's 400,000 outstanding shares for $\$ 8,000,000$. Fair value of identifiable net assets is $\$ 9,000,000$.

Assuming there were no active market price available, Company $\mathrm{P}$ could retain an independent consultant to help measure the fair value of the noncontrolling interest. Given that this independent consultant measured the fair value of the noncontrolling interest as $\$ 1,850,000$, goodwill would be calculated as follows:

Fair value of consideration transferred

Fair value of noncontrolling interest.

Fair value identifiable net assets

Goodwill....
$\$ 8,000,000$

$\frac{1,850,000}{\$ 19,850,000}$

$\$ 9,850,000$

$9,000,000$

$\$ 850,000$

Goodwill attributable to Company $\mathrm{P}$ is $\$ 800,000(\$ 8,000,000-80 \% * \$ 9,000,000)$ and goodwill attributable to Noncontrolling Interest is $\$ 50,000(\$ 1,850,000-20 \% * \$ 9,000,000)$.

\section{BARGAIN PURCHASE}

Occasionally a bargain purchase may occur in which the amount paid is less than the fair value of what is received. A forced liquidation in which the seller is acting under compulsion or a distress sale after the death of a key manager may result in this situation.

Currently this difference is allocated as a pro rata reduction of the amounts that otherwise would have been assigned to particular assets acquired. The new requirements would report the difference as a gain which should improve the respresentational faithfulness and completeness because acquired assets would remain at their fair values instead of being arbitrarily reduced in value.

A gain is recognized if the amount by which the fair value of what is acquired exceeds the fair value of consideration transferred plus the fair value of any noncontrolling interest. This calculation will result in the gain being attributed to the acquirer only.

Before recognizing any gain, the acquirer should reassess whether it has correctly identified and measured all the assets acquired and liabilities assumed. Any identification or measurement error could affect the amount of gain recognized. If an obvious reason for the bargain purchase does not exist, then it is even more imperative to have the net assets correctly identified and measured so that the recognized gain truly reflects the underlying economics of the transaction. This Statement calculates the gain as follows:

Fair value of net assets acquired $\quad \mathrm{xx}$

- (Fair value of consideration given +

fair value of noncontrolling interest) $\quad\langle\underline{x x}\rangle$

Gain recognized

$\underline{\underline{X}}$ 
Example. On January 1, 2009, Company P acquires $80 \%$ of Company S's equity interest in exchange for $\$ 2,000,000$. Because the former owners needed to dispose of their investments in Company $\mathrm{S}$ by a specified date, they did not have sufficient time to market their investments to multiple potential buyers. The identifiable assets are measured at $\$ 4,500,000$, and the liabilities assumed are measured at $\$ 1,500,000$. Company $\mathrm{P}$ engages an independent consultant who determines that the fair value of the 20 percent noncontrolling interest in Company $\mathrm{S}$ is $\$ 620,000$. The calculation of the gain from the bargain purchase is as follows:

\begin{tabular}{|c|c|}
\hline Identifiable net assets acquired & $\$ 3,000,000$ \\
\hline Fair Value of Consideratin given & $\$ 2,000,000$ \\
\hline Fair Value of Noncontrolling Interest & 620,000 \\
\hline Gain & $\frac{2,620,000}{\$ 380,000}$ \\
\hline
\end{tabular}

The consolidated statements would reflect the acquisition as follows:
Dr. Identifiable Assets
$4,500,000$
Cr. Liabilities
$1,500,000$
Cr. Cash
$2,000,000$
Cr. Equity - noncontrolling interest
620,000
Cr. Gain on bargain purchase
380,000

The total gain is attributable to Company P. The noncontrolling interest, which is an independent calculation of its fair value, actually reflects goodwill of $\$ 20,000(\$ 620,000-20 \%$ fair value of identifiable net assets).

\section{ACQUISITION RELATED COSTS}

Acquisition-related costs are costs the acquirer incurs to effect a business combination. Those costs include finder's fees, consulting fees, general administrative costs, and costs of registering and issuing debt and equity securities. Currently, those costs related to the issuance of equity securities are a reduction of Paid In Capital. All other costs are an added cost of the acquisition.

This Statement improves reporting of business combinations in that its measures the identifiable net assets at fair value and recognizes the acquisition-related costs separately from the acquisition. The acquisition-related costs are accounted for as follows:

- $\quad$ Expense in the periods in which the costs are incurred.

- $\quad$ Bond issues costs are deferred and amortized as an adjustment to Interest Expense.

- $\quad$ Stock issue costs are a reduction of additional paid-in-capital.

This Statement requires costs to issue debt and equity securities to be recognized in accordance with other applicable GAAP. However, the FASB is considering expensing all issue costs, but that issue is to be dealt with at some future date in the liabilities and equity project.

Example. Company $\mathrm{P}$ acquired Company $\mathrm{S}$ in a business combination by issuing its own equity securities. The follow acquisition-related costs were incurred:

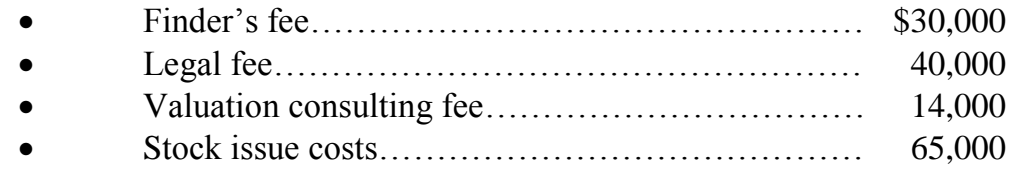

These costs would be recognized as follows: 


$\begin{array}{lr}\text { Dr. Expense } & 84,000 \\ \text { Dr. Paid In Capital } & 65,000 \\ \text { Cr. Cash } & 149,000\end{array}$

\section{CONCLUSION}

In an effort to improve the accounting for and reporting of business combinations, the FASB has issued a revised standard (SFAS 141 revised) for Business Combinations. This new Statement retains the fundamental requirements in Statement 141, but focuses on improving the recognition and measurement of the identifiable assets acquired, the liabilities assumed, and any noncontrolling interest in the acquiree. The new requirements should be applied prospectively to business combinations which have an acquisition date on or after the beginning of the first annual reporting period beginning on or after December 15, 2008. Earlier application is prohibited.

\section{AUTHOR INFORMATION}

Arlette C. Wilson, PhD, CPA, is the Taylor professor of Accounting at Auburn University in Auburn, Alabama. For the past 30 years she has taught and researched in the area of financial accounting. She has published in various academic and practitioner journals including Contemporary Accounting Research, Advances in Accounting, Journal of Applied Business Research, Accounting Horizons, and Journal of Accountancy.

Kim Key is an Associate Professor of Accounting at Auburn University in Auburn, Alabama. She teaches and researches in the areas of taxation and financial accounting. She has published in journals including Journal of Accounting and Economics, Journal of the American Taxation Association, Journal of Applied Business Research, Tax Notes, and CPA Journal.

\section{EXHIBIT 1}

\section{Accounting for Contingent Consideration}

Target Earnings

Assumption 1: Reported earnings for 2010 were \$550,000.

Previous Accounting

\begin{tabular}{l|l} 
Nov. 1 & No Entry \\
2009 & $\mid$
\end{tabular}

Dec. 31 Dr. Investment

$2010 \quad$ Cr. Liability

\section{Revised Accounting}

\begin{tabular}{l|ll} 
Nov. 1 & | Dr. Investment & 40,000 \\
2009 & | Cr. Liability & 40,000 \\
& & \\
Dec. 31 & | Dr. Loss & 15,000 \\
2010 & | Cr. Liability & 15,000
\end{tabular}

Assumption 2: Reported earnings for 2010 were $\$ 350,000$

\begin{tabular}{|c|c|c|c|c|c|}
\hline Nov. 1 & | No Entry & & Nov. 1 & | Dr. Investment & 40,000 \\
\hline 2009 & | & & 2009 & Cr. Liability & 40,000 \\
\hline Dec. 31 & Dr. Investment & 35,000 & Dec. 31 & | Dr. Liability & 5,000 \\
\hline 2010 & Cr. Liability & 35,000 & 2010 & Cr. Gain & 5,000 \\
\hline
\end{tabular}

Assumption 3: Reported earnings for 2010 were \$280,000.

$\begin{array}{ll}\text { Nov. 1 } & \text { No Entry } \\ 2009 & \mid \\ \text { Dec. } 31 & \mid \text { No Entry } \\ 2010 & \mid\end{array}$

$\begin{array}{lll}\text { Nov. } 1 & \text { | Dr. Investment } & 40,000 \\ 2009 & \text { | Cr. Liability } & 40,000 \\ & & \\ \text { Dec. } 31 & \text { | Dr. Liability } & 40,000 \\ 2010 & \text { | Cr. Gain } & 40,000\end{array}$




\section{EXHIBIT 2}

\section{Accounting for Contingent Consideration}

Security Price

Assumption 1: Fair value is $\$ 30$ per share

Previous Accounting

\section{Revised Accounting}

Nov. 1 No Entry

2009

Dec. 31 Dr. Paid In Capital

$2010 \quad$ Cr. Common Stock

$1,200,000$

$1,200,000$

Dr. Investment

Nov. 1

2009 Cr. Paid in Capital $1,600,000$

$1,600,000$

Assumption 2: Fair value is $\$ 35$ per share

\begin{tabular}{l|llll} 
Nov. 1 & No Entry & Nov. 1 & Dr. Investment & $1,600,000$ \\
2009 & $\mid$ & 2009 & Cr. Paid In Capital & $1,600,000$ \\
& & & \\
Dec. 31 & No entry & Dec. 31 & No Entry \\
2010 & $\mid$ & 2010 & $\mid$
\end{tabular}

\section{EXHIBIT 3}

Journal Entries for a Business Combination Achieved in Stages

\begin{tabular}{|c|c|c|c|}
\hline$\underline{2007}$ & \multicolumn{3}{|c|}{$\underline{2008}$} \\
\hline Dr. Investment & 130,000 & Dr. Investment & 280,000 \\
\hline Cr. Cash & 130,000 & Cr. Cash & 280,000 \\
\hline Dr. Cash & 2,000 & Dr. Investment & 8,000 \\
\hline \multirow[t]{5}{*}{ Cr. Dividend Revenue } & 2,000 & Cr. Retained Earnings & 8,000 \\
\hline & & Dr. Cash & 6,000 \\
\hline & & Cr. Investment & 6,000 \\
\hline & & Dr. Investment & 33,000 \\
\hline & & Cr. Investment Revenue & 33,000 \\
\hline \multicolumn{4}{|c|}{$\underline{2009}$} \\
\hline Current Accounting & & Revised Accounting & \\
\hline Dr. Investment & 600,000 & Dr. Investment & 600,000 \\
\hline \multirow[t]{3}{*}{ Cr. Cash } & 600,000 & Cr. Cash & 600,000 \\
\hline & & Dr. Investment & 5,000 \\
\hline & & Cr. Gain & 5,000 \\
\hline
\end{tabular}

